\title{
咬合性外傷の治癒経過に関する実験的研究
}

\author{
寺坂章 \\ 大阪歯科大学歯周病学講座 \\ （主任・指導：山岡 昭教授） \\ (昭和 59 年 9 月 20 日受付)
}

\section{A Study on Healing Progress of Traumatic Lesion}

\author{
Akira TERASAKA \\ Department of Periodontology, Osaka Dental University \\ (Chief and Director : Prof. Akira YAMAOKA)
}

The purpose of the present investgation in monkeys was to analyze the effect on periodontal lesion induced by a occlusal trauma, when the traumatic occlusion is eliminated. Trauma from occlusion was produced with cast gold high crown on each posterior tooth $\left(\mathrm{M}_{2}\right)$ of monkeys.

Initially, traumatic occlusion was given on the right posterior tooth $\left(\mathrm{M}_{2}\right)$. The traumatic occlusion was removed from the tooth by occlusal adjustment 12 weeks post-operating.

During experimental periods, monkeys were brushed the teeth and gingiva every 3 days. Oral examination was made every one week to check the taken to investigate bone and periodontal space changes. Radiographic examination was carried out once a week during experimental periods ( 70 weeks). Standardized radiographs were analyzed with PhotoPattern-Analyzer and X-Y Recorder.

The results obtained were as follows :

1. No inflammatory change of the gingiva around the experimental teeth was observed.

2. Bone resorption and widened periodontal ligament space were observed radiographically after cementing high crown. Bone resorption of experimental tooth was markedly increased and periodontal ligament space was widened 8 weeks post-operating.

3. Removal of the occlusal trauma from each experimental tooth resulted in a gradually decreased bone resorption and periodontal ligament space.

Key words : Trauma from occlusion, Standardized radiograph, Regeneration

要旨：日本ザルを用い,その下䪽右側第 2 大臼歯に咬合高径を高めた鋳造冠を装着し，当該歯部に咬合性外傷を惹起 せしめ, その後, 咬合調整によって外傷性咬合を除いた後の回復状態を臨床的およびX線規格写真学的に観察するとと もに歯槽骨のひずみ量の測定を行なった。

その結果, 奏験期間を通じて, 臨床所見とくに歯肉炎症指数, ポケットの墚さおよび歯肉溝浸出液量の測定結果など から歯肉に炎症症状は認められなかった。

一方，X線規格写真およびその写真を分析した結果より，鋳造冠装着後 8 週目までは，根分岐部歯槽骨，歯根膜腔お よび槽間中隔骨頂部のX線透過性が高くなっていくのが顕著に認められたが， 8 週目以降から 12 週目にかけてはその X線透過性の増加率は少なかった。つぎに咬合調整後の回復経過については, 調整後 8 週から 12 週目にかけて被験歯 の上述したX線透過部の顕著な減少がみられたが，それ以後の減少率は緩慢であった。

本論文の要旨は, 第 20 回秋季日本歯周病学会 (1977 年 10 月 20 日, 東京), 第 22 回春季日本歯周病学会 (1979 年 5 月 20 日, 千葉) と第 322 回大阪歯科学会例会（1984 年 1 月 21 日, 大阪）において発表した。 
他方，歯冠部に荷重を加えたとき，根分岐部に最も大きなひずみが生じることが確認できた。

索引用語 : 咬合性外傷, X線規格写真, 再生

\section{緒言}

歯周疾患の原因は，古くから局所的原因と全身的原因 とに大別されているが, 現在では局所的因子がその主役 であり，全身的因子は歯周疾患を増悪させる修飾因子に すぎないとされている。とくに，局所的因子のなかでも 歯周組織に宿主反応としての炎症をもたらす口腔内微生 物すなわち歯垢を中心とした発炎性因子と，歯周組織を 器械的に傷害する力学的な因子すなわち外傷性因子との 2 つに大別できる。

さて, 歯周疾患の発症因子としての外傷性因子につ いて歴史的に展望してみると，まず 20 世紀の初期に Karolyi, M. (1901)1) が提起し，その後 Stillman, P.R. $(1917)^{2)}$ によって外傷性咬合という言葉が提唱されて以 来, 咬合性外傷について各研究者により様々な検索がな されてきた ${ }^{3 \sim 99}$ 。

しかし，咬合性外傷について研究を行う場合，多くの 制約をうけることは周知の通りである。たとえば，第 1 に，ヒトにみられるのと同じような病変を実験動物に起 こさせることは極めて困難であることがあげられる。第 2 に, 他の因子を除外し, 外傷性咬合が単独で歯周組織 破壊にどのような影響を及ぼすかを解明することはさら に困難である。第 3 亿，咬合性外傷を取り除いた時の歯 周組織の変化を観察するためにはかなり長期間を要する などのことが挙げられる。このようなことから，咬合性 外傷の回復に関する研究としては, Lindhe, J. \& Ericsson, I. $(1982)^{10)}$, Polson, A.M., Meitner, S.W. \& Zander, H.A. $(1976)^{11)}$, Kantor, M., Polson, A.M. \& Zander, H.A. (1976) ${ }^{12)}$ の報告があるにすぎない。

そこで，今回著者は，日本ザルの大臼歯に咬合高径を 高めた鋳造冠を装着して人工的外傷性咬合を生じさせ て，咬合性外傷がどのような機序で起こるかを観察する とともに，装着した鋳造冠を咬合調整して，咬合性外傷 を取り除いた場合，歯周組織にどのような修復反応が現 われるかを，規格 X線写真ならびに臨床的所見によって 経週的に観察し，また，規格X線写真の変化をより客観 的にとらえるために, Photo pattern analyzer によって 等濃度分析を行い，さらに歯に垂直荷重を加えた場合の 歯槽骨のひずみ量の大きさを観察して，ひずみ量とX線 透過像との関連性を明らかにしたので，その結果につい
て報告する。

\section{実験動物}

全身的に異常がなく，両側の下顎第 3 大曰歯が萌出し た，正常な永久歯歯列を有する日本ザル 7 頭を用いた。

飼料として，サル用固型飼料 (オリエンタル社製)，り んご，かきおよびいも等の季節の果物や野菜と水道水と を与えた。

\section{実験方法}

実験開始に先立って，ブラッシングおよびスケーリン グを行い,できるだけ歯垢および歯石の除去につとめ た。すなわち, Löe, H. \& Silness, J. $(1967)^{13)}(1963)^{14)}$ $\curvearrowright$ Gingival Index (GI) と Green, J.C. \& Vermillion, J.R. $(1960)^{15)}$ の Oral Hygine Index (O.H.I.) および PERIOTRON ${ }^{\circledR}$ HAR-600 (HARCO ELECTRONICS LIMITED 製) を用いて ${ }^{16)}$ G.C.F. 值 (Gingival crevicular fluid 值)を一定值以下になるようにした。

右側下顎第 2 大臼歯を被験歯とし，左側下顎第 2 大臼 歯は対照歯とした。すなわち被験歯に歯軸方 向（歯冠一 歯根方向）に外傷性咬合が加わるように鋳造冠を作製 し，アイオノマーセメントで支台歯に合着した。

なお，鋳造冠の維持をよくするために，両隣接面のみ 歯肉縁部まで支台形成し，また，冠縁による歯肉の刺激 を避けるため, 唇舌側部の冠縁を約 $1.5 \mathrm{~mm}$ 歯肉縁上に 設定した。

また，鋳造冠の作製には，あらかじめ作っておいたレ ジン製各個トレーによって寒天・アルギン酸の連合印象 を行い, 硬石亮で作った作業用模型を Gysi の平均值咬 合器に通法に従って装着し, ガイドピンを $1.5 \mathrm{~mm}$ 高め てワックスパターンを作製し，金合金（三金工業社製タ イプIII）で鋳造した。

鋳造冠装着日から 12 週間咬合性外傷の状態を観察し, ついで咬合調整を行ってさらに 58 週間咬合性外傷の 回 復の経過を観察した。

なお，咬合調整の際には，支台形成前の考究用模型を 参考に，咬合紙を用いて調整すると同時に，エアーブラ シを用いて機能的な咬合調整を行い，外傷性咬合が働か ないようにした。 


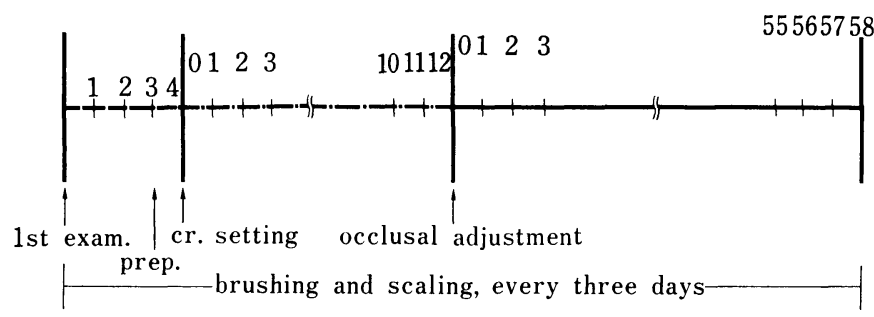

Fig. 1 Observation periods

また，全観察期間を通じて，口腔内全体を染色液 (John O. Butler 社製 Red-Cote) にて染色し，3 日毎に ブラッシングを行い，歯肉に炎症を生じさせないように 配慮することにより, 歯周組織, とくに歯肉を臨床的に 正常な状態に保った。

\section{観察方法}

鋳造冠装着後 1 週間ごとに，観察期間中を通じて次の 項目について診査した (Fig. 1)。

1. 体重の変化 : 体重計により計測した。

2. 口腔内の状態 : Red-Cote による染色前・後の口 腔内カラースライド写真の撮影を行い，記録した。

使用カメラはメディカルニッコールで，倍率を 1 倍に し撮影した。フィルムはフジクローム 100 を用いた。

3. 歯垢の沈着状態 : Green, J.C. \& Vermillion, J.R. $(1960)^{15)}$ の O.H.I. にて評価をした。

4. 歯肉の状態 : Löe, H. \& Silness, J. (1967) ${ }^{13)}$ $(1963)^{14)}$ の Gingival Index を用いて評価した。

5. ポケットの深さ：被験歯および対照歯の近心・遠 心・煩側および舌側の 4 点をポケットプローブ（山浦製 作所製）によって計った。

6. 歯肉溝滲出液量 : 被験歯および対照歯の頖側歯肉 溝からの滲出液 ${ }^{17,18)}$ を通法に従って PERIOTRON® を 用いて 3 回測定し，その平均值を求めた。

7. 規格 X線写真 : 被験歯および対照歯の 歯 根膜腔 や, 周囲の歯槽骨の変化を観察するため, 規格X線写真 を撮影した。

規格 X線撮影装置については, Irwin, J.P., Victor,

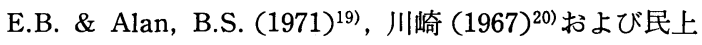
$(1982)^{21)}$ 等の報告があるが，今回著者は 民上 $(1982)^{21)}$ の考案したものを用いた。

なお，用いたX線発生装置は，ORAX（モリ夕社製） で，これに $200 \mathrm{~mm}$ のロングコーンを装着して使用（管 電圧 $70 \mathrm{kVp}$, 管電圧 $10 \mathrm{~mA}$ で $0.7 \mathrm{sec}$. 曝射)した。また,

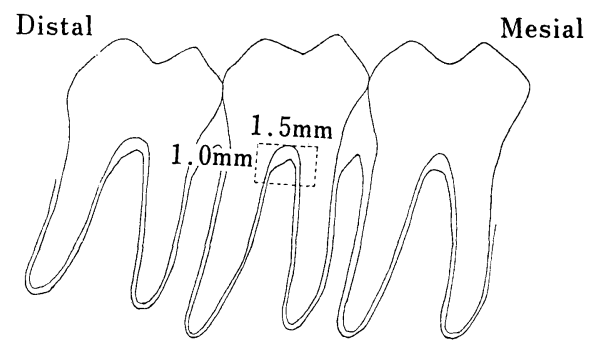

Fig. 2 Measuring area of bone absorbtion

フィルムは小児サイズ $(24 \times 30 \mathrm{~mm}) \mathrm{X}$ 線フィルム（阪 神技術研究所社製ブラック $\mathrm{BCW}$ ) を使用した。

フィルムの現像は民上 (1982) ${ }^{21)}$ の行った方法に準 じ た。すなわち, 自動現像器 (フジ社製) を使用するなど 規格化をはかった。

さらに，現像したX線フィルムを，より客観的にとら えるために Photo pattern analyzer (Applied electric Lab. Co., LTD. 製 Model PPA-250 MFG No. 124）を 用いて等濃度分析を行った。

その際の機器の設定条件として, 根分岐部の変化がよ く観察できるアルミ斜面の厚さ $4 \mathrm{~mm}$ 以下と同じ濃度幅 で，また，歯根膜空隙の変化を明確にできるアルミ斜面 の厚さ $4.5 \mathrm{~mm}$ 以下と同じ濃度幅の 2 種類を設定した。

8. 根分岐部の X線透過面積 : 規格 X線写真を日本光 学社製万能投影機 (Profile Projector Model 6C) を用い て 10 倍に拡大し, 被験歯の根分岐部における経週的な 歯槽骨のX線透過面積を計測した。

計測範囲は Fig. 2 に示すように, 根分岐部の歯冠側に 接線を引き，接点を中心に横（近遠心方向）に $1.5 \mathrm{~mm}$, 縦（歯軸方向）に $1.0 \mathrm{~mm}$ の範囲とした。

9. 歯の沈下 : 規格 X線写真を利用して, 前述の根分 岐部の X線透過面積の測定と同様に万能投影機にて 10 倍に拡大し，測定した。すなわち，右側第 1 大臼歯と第 3 大臼歯との咬頭頂を結ぶ值線から被験歯の冠縁までの 垂值距離を測定した (Fig. 3)。 


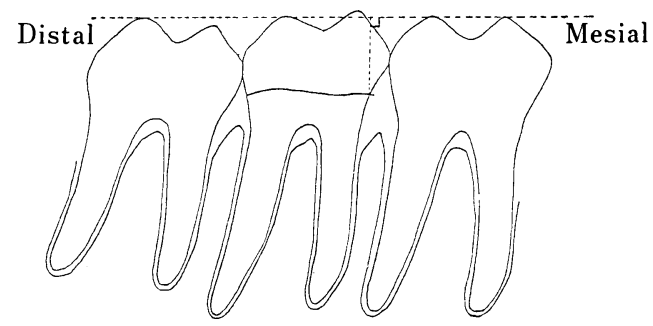

Fig. 3 Measuring method of depressing tooth

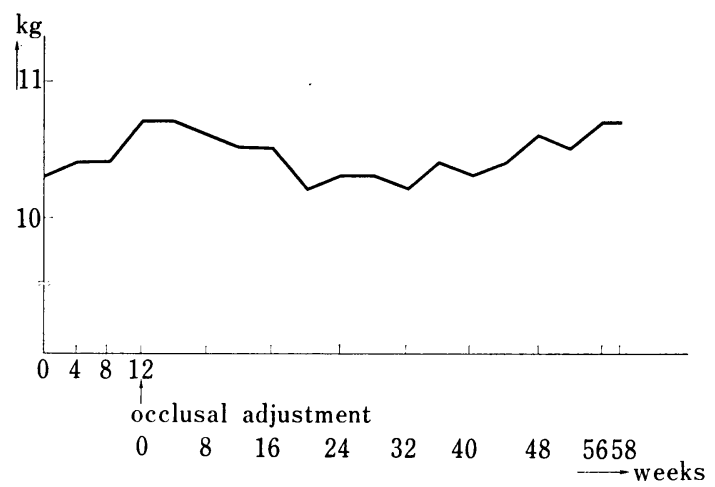

Fig. 5 Body weight (changes of experimental periods)

10. ひずみ量 : 被験歯の近心辺縁隆線, 遠心辺縁隆線 および中央窩に垂直荷重を加えた時の，被験歯の近心側 および遠心側の槽間中隔部ならびに根分岐部の歯槽骨に 生ずる歯軸方向のひずみ量を測定した。

すなわち，ケタラール（三共株式会社製動物用ケタラ 一ル 50) による全身麻酔 (0.1〜0.2 ml/体重 $\mathrm{kg}$; 筋肉内 注射）下で頸動脈の切断によって失血死させて摘出した 下顎骨を，そのオトガイ部において左右側の下顎骨体に 切断, 分離した。

ついで，歯科用トリーマーを用いて下顎骨体を矢状断 し，その断面骨表面にストレインゲージ（単軸ストレイ ンゲージ； B-FAE-1S12-T11 W 03, 新興通信工業製) を 貼布した (Fig. 4)。

なお，ひずみ量の測定は，杉村 $(1979)^{22)}$ の方法に準 じて行った。

\section{実験成績}

1. 鋳造冠装着後やや体重の減少傾向がみられたもの の, その後は徐々に増加の傾向を示し（Fig. 5), 全観察 期間を通じて顕著な変化はみられず，しかも，全身状態

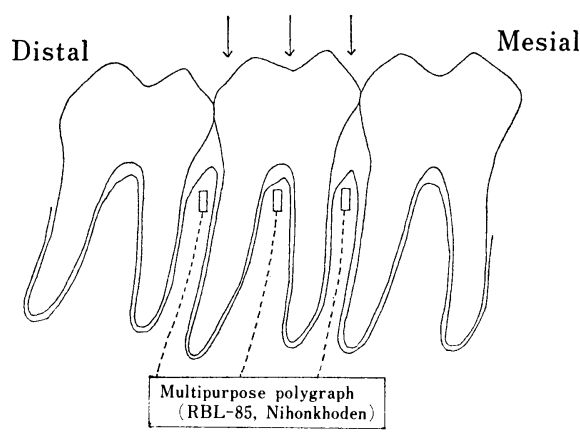

Fig. 4 Measuring position of strain guage and Adding force direction

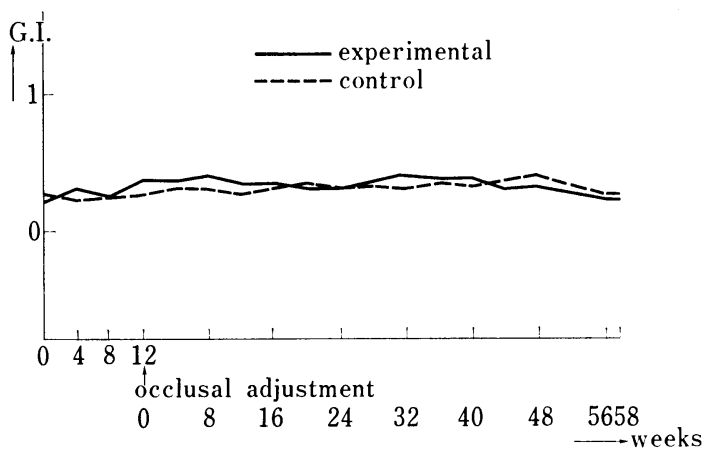

Fig. 6 Gingival index (changes of experimental periods)

も良好であった。

2. 口腔内とくに歯肉に関しても，肉眼的所見による 異常はとくに認められなかった。

3. 歯垢の沈着量も軽微であり, Debris Index の值は 0. 5〜1.3 であった。Calculus Index の值は 0〜0.2 であ った。

しかしながら，実験に先立って行った前準備期間中に 徹底したブラッシングおよびスケーリングを行い，歯垢 の沈着量を 0 にした状態で実験を開始したが，観察期閒 中とくに下顎前歯部舌側にわずかの歯石沈着がみられ た。この場合, ハンドスケーラーにて歯石除去を行っ た。

一方，歯垢の沈着は下影臼歯部舌側にみられたが， 3 日目毎のブラッシングにより除去した。全体的に歯垢の 沈着量は軽微であり，観察期間中の O.H.I. は 0. 7〜 1. 5 で, 大きな変化は示さなかった。

4. 歯肉炎症指数については, 観察期間中を通じて, 被験歯側および対照歯側ともに大きな差はなく，常に 1 以下を示した（Fig.6)。 


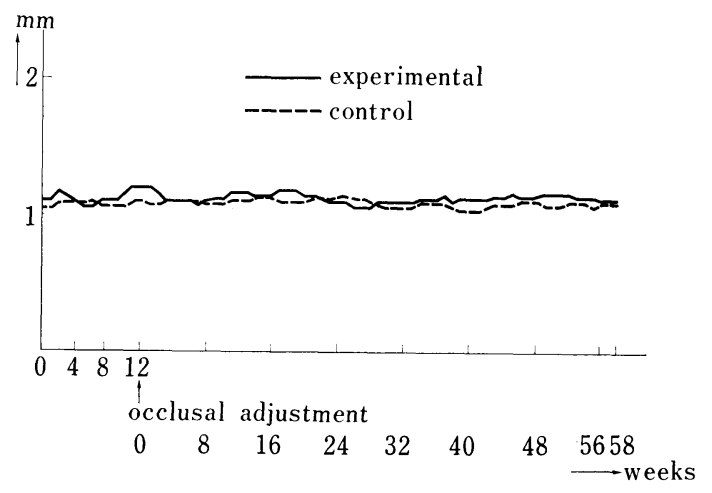

Fig. 7 Pocket depth

(changes of experimental periods)

5. ポケット測定の結果，実験開始前のポケットの深 さは約 $1 \mathrm{~mm}$ で, 被験歯および対照歯ともに観察期間中 ほとんど変動を示さなかった (Fig. 7)。

6. 歯肉溝浸出液量 (G.C.F. 值) については, 観察期 間中を通じて多少の変動がみられたが，被験歯および対 照歯ともに 5 前後の値を示していた (Fig. 8)。

7. 規格X線写真の経週的な変化について, 代表的な ものを Fig. 9〜21 に示した。この規格X線写真をより客 観的に観察するために, Photo Pattern Analyzer にて分 析したもの（以下 A 分析図と称す）が Fig. 22〜34 であ り, また, 歯根膜空隙の変化をより明確にするために, 観察方法の項ですでに記述したように，方向および濃度 幅を変えて分析したもの（以下 B 分析図と称す）が Fig. 35〜 47 である。

まず，対照歯について記述すると，観察開始日および 最終観察日を比較した場合，規格X線写真 (Fig. 9, 10), A 分析図 (Fig. 22, 23) および B 分析図 (Fig. 35, 36) と もに両者の間にはほとんど差異は認められなかった。

つぎに, 被験歯を経週的に規格X線写真，A 分析図お よび B 分析図とを比較してみると, 被験歯に鋳造冠を装 着した直後の規格X線写真 (Fig. 11)，A分析図 (Fig. 24), B 分析図 (Fig. 37) と, 被験歯に鋳造冠を装着して 1 週間を経過したものを比較すると, 後者にやや歯根膜 空隙部に桩大が認められたにすぎなかった。しかし，鋳 造冠装着後 2 週目の規格X線写真 (Fig. 12) では, 歯根 膜空陌の拡大とともに根分岐部歯槽骨の X線透過性も増 加してきている。A 分析図 (Fig. 25) においても, 根分 岐部歯槽骨のX線透過性の増加は明確であり, B 分析図 (Fig. 38) では槽間中隔部骨頂付近の歯根膜空隙の 抗大 がやや増加しているのが認められた。

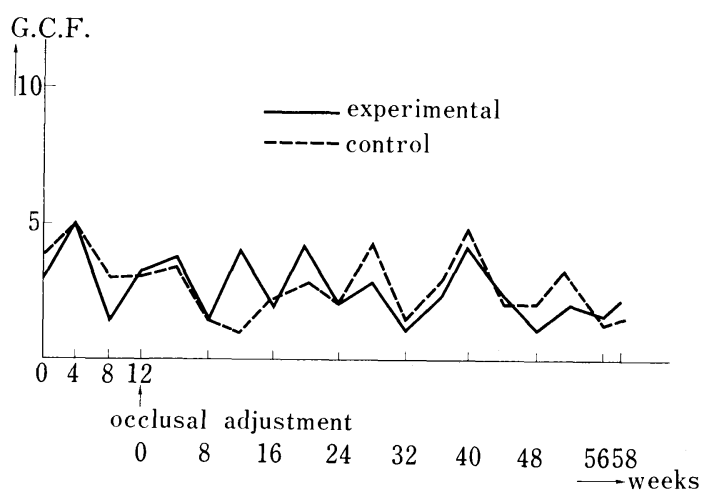

Fig. 8 G.C.F. value (changes of experimental periods)

3 週目では根分岐部歯槽骨のX線透過性がさらに顕著 となり，歯槽硬線がやや消失してきていた。

Fig. 13 は 6 週目の規格X線写真であるが，この時期 より近心側と遠心側との槽間中隔部の歯槽骨の垂直的な X線透過像がやや認められ, 8 週目 (Fig. 14) でその傾向 がさらに著明になるとともに根分岐部の歯槽骨のX線透 過性が増大し, 11 週目（Fig. 15), 12 週目では槽間中隔 部の歯槽骨においてもX線透過性の増大が著明になって きている。

一方，A分析図においても明らかなように，鋳造冠装 着後 6 週目（Fig. 26）で，それ以前に比較して根分岐部 の歯槽骨のX線透過性がさらに増加し, 8 週目 (Fig. 27)，11 週目（Fig. 28）に至っては根分岐部の歯槽骨の $\mathrm{X}$ 線透過性の顕著な増大のみならず，近心側と遠心側と の槽間中隔部の歯槽骨のX線透過性も増大してきている のが確認できた。

他方，B分析図でも A 分析図の場合と同様に, 鋳造冠 装着後 6 週目（Fig. 39）でそれ以前に比較して歯根膜空 隙のX線透過性が増し, 8 週目 (Fig. 40) ではX線透過性 の度合いがさらに著明になり，11 週目（Fig. 41）では， それがより顕著に認められた。

以上が被験歯に咬合高径を高めた鋳造冠を装着し，咬 合性外傷を惹き起こさせたときの規格X線写真および分 析図であるが，つぎに，咬合調整を行うことによって， 咬合性外傷を取り除き, その回復の経過を規格X線写真 および分析図で観察した結果について記述することにす る。

すなわち, 咬合調整後 3 週目までは, 咬合調整を行う 前の状態と, 規格 $\mathrm{X}$ 線写真, $\mathrm{A}$ 分析図および B 分析図と もにさしたる変化は認められなかった。しかし，咬合調 


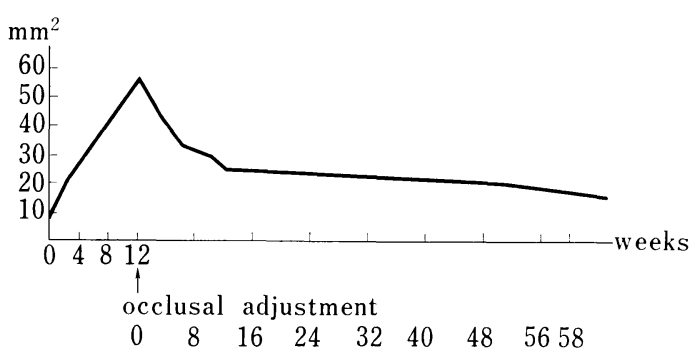

Fig. 48 Absorbtion area of bone (changes of experimental periods)

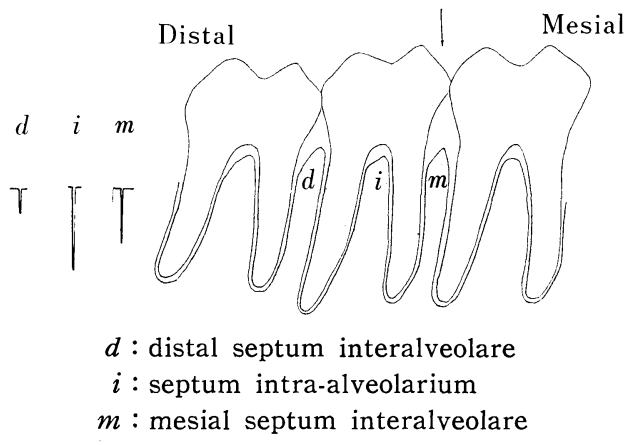

Fig. 49 Strain of mandible with application of vertical load to tooth on sagittally-cut mandible

(adding force to mesial marginal ridge)

整後 4 週目（Fig. 16，29，42）ごろから歯根膜腔と根分岐 部の歯槽骨のX線透過性の減少が明らかになり，咬合調 整後 7 週目の規格X線写真（Fig. 17）では，根分岐部の 歯槽骨のX線透過性の改善が顕著であり, しか子歯槽硬 線もやや認められた。一方，同時期の A 分析図 (Fig. 30)では，根分岐部抢よび両隣接部の歯槽骨の X線透過 性の減少が観察でき, 他方, B 分析図 (Fig. 43) では, 遠 心側歯根膜腔の X線透過性の減少が認められた。

12 週目では, 規格 X線写真 (Fig. 18), A 分析図 (Fig. 31) および B 分析図 (Fig. 44) ともに 7 週目のものと比 較して, 歯根膜空隙と根分岐部の歯槽骨のX線透過性が わずかに改善されてきていた。

その後, 1 週目毎の経過では著明な変化は認められな かったが, 咬合調整後 25 週目の規格X線写真 (Fig. 19), A 分析図 (Fig. 32) およびB 分析図 (Fig. 45), さ らに, 咬合調整後 42 週目の規格X線写真 (Fig. 20), A 分析図 (Fig. 33) およびB 分析図 (Fig. 46) でも明らか なように, 週を追って確実に歯根膜空隙之根分岐部の歯 槽骨とのX線透過性が改善され，最終観察日である咬合
Table 1 Score of depressing tooth mean value $(\overline{\mathrm{x}})$, standard deviation (S.D.)

\begin{tabular}{cccc}
\hline & & $(\mathrm{mm})$ \\
\hline & weeks & $\overline{\mathrm{x}}$ & S.D. \\
\hline & 0 & 4.739 & 0.018 \\
2 & 4.743 & 0.032 \\
& 6 & 4.759 & 0.026 \\
& 8 & 4.754 & 0.012 \\
occlusal adjustment & 11 & 4.755 & 0.031 \\
& 4 & 4.758 & 0.013 \\
& 8 & 4.756 & 0.023 \\
& 11 & 4.755 & 0.032 \\
& 25 & 4.760 & 0.014 \\
& 42 & 4.758 & 0.038 \\
& 58 & 4.753 & 0.018 \\
\hline
\end{tabular}

調整後約 1 年目, すなわち, 58 週目の規格X線写真 (Fig. 21), A 分析図 (Fig. 34) および B 分析図 (Fig. 47) では, 鋳造冠装着直後とほぼ同様にまで歯根膜空隙と根 分岐部の歯槽骨とのX線透過性が改善されていた。

8. 根分岐部の歯槽骨のX線透過部を万能投影機にて 10 倍に拉大し, その面積を計算した結果, Fig. 48 亿示す ように, 冠装着直後から咬合調整を行う 12 週目にかけ て著しくX線透過面積が増加し, 咬合調整後も 12 週目 にかけて透過面積の著明な減少が認められた。それ以降, すなわち咬合調整後 13 週目から 58 週目にかけて, 徐々 にではあるが透過面積の減少傾向が認められた。

9. 被験歯の沈下に関して, 咬合調整を行うまでの沈 下はほとんど認められなかった (Table 1)。

10. 近心辺徍隆線, 遠心辺縁隆線および中央窝のそれ ぞれに垂直荷重を加えた時の被験歯の近心側の槽間中隔 部，遠心側の槽間中隔部および根分岐部の歯槽骨に生ず るひずみ量を測定したところ，どの部位に荷重を加えて も，根分岐部において最も大きなひずみが，そして遠心 側の槽間中隔部では最も小さなひずみが現われた（Fig. 49 51)。

\section{考察}

\section{1. 実験方法について}

実験動物の歯周組織に対して外傷性の変化を惹き起こ させる研究はこれまで数多くなされ，その中，外傷性咬 合を惹き起こさせる方法についてもいろいろの手段が用 いられてきた。たとえば，その一つに歯に咬合を高めた 


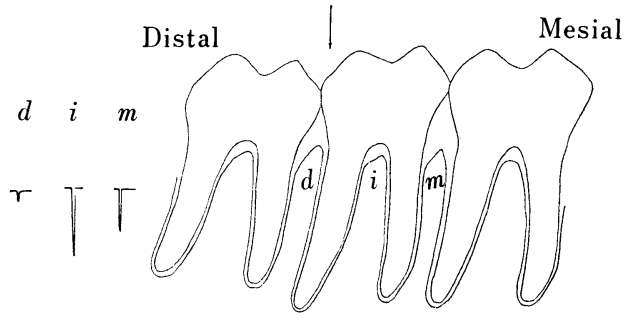

$d:$ distal septum interalveolare

$i$ : septum intra-alveolarium

$m:$ mesial septum interalveolare

Fig. 50 Strain of mandible with application of vertical load to tooth on sagittally-cut mandible

(adding force to distal marginal ridge)

歯冠修復物を装着する方法3,6,7,22 25)があり，その修復物 としてはアマルガム，インレーおよびクラウンなどを利 用したものが多い。また，その他の方法として矯正装置

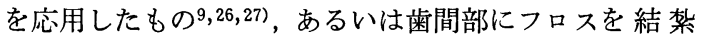
したり楔を挿入する方法4,5,29)などがある。

今回著者は，鋳造冠を装着する方法を用いたが，この 方法には経時的に被験歯が沈下しやすく, 結果的に咬合 力が外傷的に働かなくなりやすいという欠点があると言 われている ${ }^{25,26)}$ 。しかしながら，矯正装置を応用したも のや結紮したり楔を挿入したりする方法では，被験歯の 沈下といら久点は少ないが，装置の調整が繁雑であった り, 加わる力の方向や強さをコントロールするのが難し いとされている。その点, 鋳造冠による方法は, 咬合の 高さや力の方向を比較的容易に把握することができると いう利点があり, 今回, 著者が用いた理由もここにあ る。

ところで，鋳造冠を装着して咬合性外傷を惹き起こさ せるという方法については, 過去において多くの場合, 鋳造冠の高さを高めるとともに近心隣接歯の歯冠を切断 して鋳造冠を近心方向へテラス状に延長し, 被験歯に外 傷性の咬合力を働かせる方法が多くとられてきた。しか し, この方法によると被験歯が近心に傾斜し, 被験歯の 動摇および沈下の程度が大きくなり, 咬合力が外傷性に 働かなくなる傾向がみられる。この欠点を防ぐため, 著 者は被験歯の両隣接歯の接触点を回復させるような鋳造 冠を装着し，外傷性に働く咬合力をできるだけ歯軸方向 に限定し，被験歯の傾斜という状態をなくするようにし た。その結果, 被験歯の沈下実験で記述したように, 鋳 造冠装着時と咬合調整を行った時点での被験歯の沈下は ほとんど認められなかった。しかも鋳造冠装着時から経

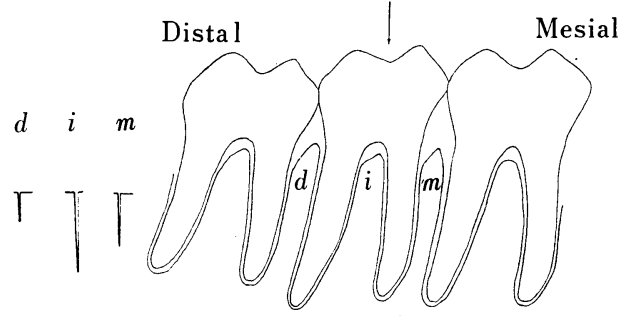

$d:$ distal septum interalveolare

$i$ : septum intra-alveolarium

$m:$ mesial septum interalveolare

Fig. 51 Strain of mandible with application of vertical load to tooth on sagittally-cut mandible

(adding force to central fossa)

週的に撮影した規格 X線写真において，被験歯の根分岐 部等の透過性が増加していることからも，咬合調整を行 うまでの間常に咬合性外傷が働き続けていたと考えられ る。

さて，近年になって，咬合性外傷に炎症が加わった場 合，放置すれば不可逆的な歯周障害をもたらすというこ とが次第に定着してきている。そこで，実験動物の口腔 内状態を良好に保つため, 3 日目毎に麻酔下でブラッシ ングを行った。これよりさらに頻回ブラッシングを行え ば良いと思われるが，実験動物が頻回の麻酔によって全 身的な衰弱をきたすことからこの間隔が限度と考え， 3 日目毎の口腔内清掃にとどめた。しかしながら, O.H.I., GI, ポケットの深さおよび G.C.F. 值が実験期間を通じ てあまり変化を示さなかったことより，この間隔での口 腔清掃でも充分に良好な口腔内清潔状態が維持できたと 考えられる。

つぎに，咬合調整についてであるが，加藤 $\left.(1978)^{30}\right)$ が 述べているように，咬合調整とは，歯質（とくに早期接 触部）を選択的に削合し，歯に加わる外傷を取り除き， 歯周組織に生じた咬合性外傷を改善するとともに，咀嚼 筋や顎関節の異常の原因を除いて，咀嚼系全体が調和の とれた円滑な機能を営めるようにすることであり，その 基本として早期接触部を削除することである。しかし， これとともに側方圧をできるだけ取り除き, 安定した咬 頭嵌合位を確立させなければならない。その上，このよ うな調整だけではなく, 削合後の歯冠形態の調整をも必

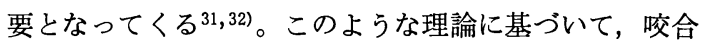
調整を行った後, さらに動的な経過を診查し, より細部 にわたった咬合調整を行うために，エアーブラシを用い て鋳造冠を曇らせ，咬合後光沢を生じた面についての調 
整を行った

以上のような咬合調整を行うことにより鋳造冠装着前 と同様な咬合関係がもたらされ，そのことが規格 X線写 真における歯根膜空隙，根分岐部歯槽骨および槽間中隔 部歯槽骨の透過性の改善となって現われてきたと考えら れる。

一方，規格X線撮影装置については，民上 $(1982)^{21)}$ の 方法を用いたが，この装置を用いた理由は，製作が容易 であるとともに規格精度が極めて高く，強固であり，春 験期間中を通じて破損することなく使用可能なためであ る。このようにX線写真の規格化をはかるとともに,さ らに規格X線写真をより客観的に観察するために Photo Pattern Analyzer で分析を行った。しかも, 主に根分岐 部の透過性を観察する分析図 A および歯根膜空隙の透 過性を観察する分析図 B の二方向より分析した。

他方, 実験動物の局所的, 全身的変化を調べ，異常が ないかを確認する目的で, 体重の測定, 口腔内カラー写 真, ポケット測定, 歯肉溝浸出液量の測定などを行っ た。歯肉に炎症が生じている場合, その歯肉炎症指数が 増加するに伴い歯肉溝浸出液量も増加する ${ }^{25)}$ という報告 があり，それらを総合して今回の実験動物に全身的な異 常が生じなかったか, また歯肉に炎症が生じていないか を確認した。

さらに, 歯周ポケットの測定を行い, 咬合性外傷それ のみでは歯肉炎や歯周ポケットなどの炎症性変化を生じ ないという先人達の報告 $3,7,27,34)$ と一致するかどうかを 検索した。

また，ひずみ測定については，ストレインゲージを用 いて歯および顎骨表面の変形状態を研究した 報告22, 35 37) は多いが, 下頢骨体の矢状断表面のひずみ量を測定 した実験 ${ }^{22)}$ は少ない。

著者は，歯に垂直荷重を加えたとき，歯槽骨のどの部 位に著しく大きなひずみが現われるかを明らかにするた

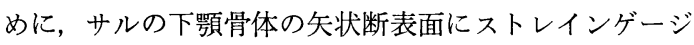
を貼布して測定したが，この方法は歯根周辺の力学的メ カニズムを解明するためには非常に有効な方法であると 考える。

\section{2. 実験成績について}

観察期間を通じて, 実験動物の口腔内状態および全身 状態はともに異常はなく，良好な経過をたどった。

Glickman, I. \& Smulow, J.B. $(1962)^{38)}(1965)^{39)}$ $(1967)^{40)}$ によるアカゲザルを用いた動物実験とヒトの剖 検結果とから, 通常は歯周組織に炎症が存在し, さらに 咬合性外傷が合併するとその影響により直接歯根膜へ炎
症が波及し，その結果樑い骨縁下ポケットや垂直性骨吸 収が生ずると述べているが，本実験では 3 日目毎のブラ ッシングおよび歯石沈着の状態に応じたスケーリングに よって発炎性因子を可及的に除去することにつとめた。 その結果，O.H.I. および GI 值も実験開始日から実験 終了日までさしたる変化は認められず，さらに炎症状態 を生じていないことを確認するために，近年，客観的な 評価方法とされている歯肉溝浸出液量を測定した。その 測定結果も観察開始日から観察終了日までさしたる変化 はなく，歯肉の安定した状態が維持できたといえる。こ のことは，本間 (1977) ${ }^{25)}$ が報告しているように，歯肉 に炎症が生じた場合, 歯肉炎症指数は経日的に増加し, 同様に歯肉溝漫出液量も増加するという報告と逆説的に 一致するものである。

また, ポケットプローブによるポケットの測定結果よ り，その深さは観察期間を通じて約 $1 \mathrm{~mm}$ 程度を維持 し，ほとんど変化はなかった。よって，本実験ではポケ ットの形成も生じなかったといえる。このことは，咬合 性外傷のみによっては歯周ポケットの形成などの炎症性 変化が生じないという過去の報告 $3,7,27,34)$ とよく一致し, この実験期間を通じて実験動物の口腔内清掃状態は良好 であり，歯肉の炎症を伴わず，被験歯に対しては咬合高 径を高めた鋳造冠による咬合性外傷のみが生じていたと 考えられる。

一方，実験的外傷性咬合における歯周組織とくに歯槽 骨の変化について, X線学的に研究したものは少なく, わずかに谷口 $(1965)^{23)}$ 浦井 $(1973)^{41)}$ の報告はあるもの の, 咬合調整を行って後の回復までを観察しているもの は皆無に等しい現況である。そこで, 本実験のX線規格 写真の観察結果について考察してみると, まず, 鋳造冠 を被験歯に装着した時点での対照歯の規格X線写真と, 実験の経過観察終了時の対照歯の規格X 線写真との比較 では，両者の間にはほとんど相違はなく, Photo Pattern Analyzer で分析した結果についても両者の間には差異 はなかった。これは被験歯に鋳造冠を装着し咬合挙上を 行ったために，対照歯が咬合していなかったものの，そ の期間が 12 週間と短く，その後正常な咬合関係に回復 したことによって廃用萎縮等の変化に陷らなかったと思 われる。

つぎに, 被験歯については, 鋳造冠を装着したのち, 規格X線写真では, 経週的に根分岐部の透過性が増加 し, 8 週目までは根分岐部の透過性が高くなっていくの が顕著に認められたが, 8 週目以降から 12 週目にかけて の透過性の増加は少なく, これは咬合性外傷に対する歯 
周組織の防禦反応として歯槽骨が緻密になりつつあるの か，また鋳造冠の咬合面に facet が生じたため, 咬合高 径を高めた鋳造冠の外傷性としての働きが弱まったこと に由来するなどが考えられる。しかし，この時点での被 験歯の動摇や沈下が認められていないことから，本間ら $(1977)^{25)}$ の報告のように，被験歯が沈下することによっ て外傷性咬合としての働きが無くなったとは考えられな い。事実，被験歯の近心 ·遠心の歯根膜腔も，根分岐部 の透過性の増加と同様に, 規格 X線写真での透過性が増 加し，歯根膜腔の幅が増加してきている。さらには，槽 間中隔の骨頂部の透過性も増加してきており，これらの ことを総合して，明らかに鋳造冠装着後 12 週目までは, その鋳造冠は外傷性の因子として働いていたと考えられ る。

一方，本実験における被験歯周囲の強度の歯槽骨破 壊，あるいはそれに伴う被験歯の動摇など重篤な臨床症 状は，今回観察できなかったが，より長期の外傷性咬合 を加えることにより, さらに広範囲の歯槽骨の透 過像 と,ひいては, 被験歯の動摇も観察できるのではないか と考えられる。

さて,つぎに咬合調整後の歯周組織の回復経過につい て記述してみると, 被験歯に咬合高径の高い鋳造冠を装 着し 12 週目で咬合調整を行ったが，この咬合調整後 8 週から 12 週目にかけて被験歯の根分岐部歯槽骨および 近・遠心部の歯根膜空隙の透過性の顕著な減少がみられ た。それ以降，すなわち咬合調整を行って 15 週目くら いから観察終了の 58 週目にかけては，ごくわずかずっ ではあるが被験歯の根分岐部歯槽骨および近・遠心部の 歯根膜空隙の透過性が次第に減少してきている。この結 果より，一旦，咬合性外傷に陥った場合，たとえ咬合調 整によってその症状が改善されるとしても, 咬合調整後 早期に顕著な改善が認められるが，その後改善は緩慢と なり，元に復するにはかなり長期を要するのではないか ということを示唆している。

また，歯が動摇し，その歯根膜腔が拡大している場合 でも，歯周組織に炎症が伴っていない場合，咬合調整を 行うことによって歯根膜空隙が正常の状態に回復すると いう Lindhe, J. \& Ericsson, I. (1982) ${ }^{10)}$ の報告, あるい は Göteborgs 大学に㧍ける Post-Graduate Course での 研究報告 $(1982)^{42)}$ で述べられているのと同様な結果が 本実騃でも確認することができた。すなわち，咬合性外 傷に陥った歯であっても，その歯周組織に炎症が伴って いなくて，しかも骨破壊の程度が軽度であり，歯根膜腔 の拡大等による歯の動摇が生じている場合, 咬合調整を
行うことにより, その歯の動摇が減少し, また歯根膜空 隙の幅む改善される一可逆的である一と考えられる。

以上, 今回の実験では咬合性外傷がどのような機序で 起こり,また，咬合性外傷を取り除いた場合，歯周組織 にどのような修復反応が起こるかについて，主に規格 X 線写真撮影とその分析図による観察を行ったが, 病理組 織学的検索を加えるのが今後の課題であるといえる。

最後に，咬合高径の高い鋳造冠を装着したとき，被験 歯周囲の歯槽骨にどのようなひずみが生じているかを調 べるために，矢状断した下頡骨体について，右側下顎第 2 大臼歯の近心辺縁隆線，遠心辺縁隆線および中央窩の それぞれに垂直荷重を加えたときの，被験歯の近心側お よび遠心側の槽間中隔部と，根分岐部の歯槽骨とにおけ る歯軸方向のひずみ量を，杉村 (1979) 22) の方法によっ て測定したところ, どの部位に垂直荷重を加えても, 被 験歯の根分岐部の歯槽骨に最も大きなひずみが現われ た。

この結果は, イヌの下顎骨を用いて実験した杉村 $(1979)^{22)}$ の成績と全く同じであった。ヒトとサルおよび イヌとでは, 歯の形態掠よび歯冠-歯根長比が異なるが, ヒトについても, 著者および杉村 $(1979)^{22)}$ が行ったサル やイヌについての実験結果と同じ成績が得られるである うと思われる。

したがって，咬合高径の高い鋳造冠を装着した場合， 早期接触によって咬合性外傷が惹き起こされるときに は，その歯の根分岐部の歯槽骨に最も大きなひずみが生 じ，その結果根分岐部に相当する歯槽骨に最も大きな障 害が現われることは容易に考えられる。

このことは, 咬合高径の高い鋳造冠を装着した被験歯 の規格 X線写真による観察結果, すなわち, X線の透過 性の増加が根分岐部の歯槽骨に最も早期に現われ，しか もその程度も他の部位と比較して大きいという事実と一 致するものである。

\section{結 論}

日本ザルを用い，その下狉右側第 2 大臼歯に咬合高径 を高めた鋳造冠を装着し，当該歯部に咬合性外傷を惹起 せしめ, その後, 咬合調整によって外傷性咬合を取り除 いた後の回復状態を, 臨床的およびX線規格写真学的に 観察するとともに，歯槽骨のひずみの測定を行った。

その結果，次のような結論を得た。

1. 本実験期間中，サルの全身状態は良好であった。

2. 被験歯について GI, O.H.I., G.C.F. 值, ポケッ 
卜測定を行った結果，被験歯歯周組織に歯肉炎などの炎 症症状は認められず，被験歯に対して咬合性外傷のみを 与えることができた。

3. 咬合性外傷が惹き起こされた 12 週の間, 被験 歯 の沈下による咬合性外傷の消失は認められなかった。

4. X線規格写真および分析図より，対照側は実験期 間を通じて変化は観察できなかった。実験側において は，鋳造冠装着後 2 週目で, $X$ 線的には早くも歯根膜腔 の拡大および根分岐部の透過性が認められ，6 週を経 過 すると分岐部の歯槽骨のX線透過性が高度になり，しか も，槽間中隔部の歯槽骨にまでX線透過性が波及してい た。

5. 咬合調整後の回復経過についてみると, 調整後 4 週目で歯根膜腔および根分岐部の歯槽骨のX線透過部の 改善が認められ, 7 週目でより明確な改善が認められた。 なお，その後は徐々に歯根膜腔および根分岐部の X線透 過性が改善される傾向にあった。

6. 被験歯の近心辺縁隆線, 遠心辺縁隆線および中央 窝に垂直荷重を加えたとき，最も大きなひずみ量を示し たのは被験歯の根分岐部に相当する槽内中隔部の歯槽骨 であった。

稿を終わるにあたり,ご指導とご校閲を賜わった山岡 昭教 授に深甚の謝意を表します。

また, 種々御助言をいただいた生理学教室覚道幸男教授なら

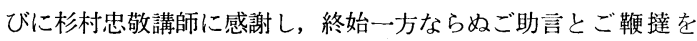
いただいた上田雅俊講師はじめ教室員各位に併せて厚く感謝い たします。

\section{引用文献}

1) Karolyi, M. : Beobachtungen uber Pyorrhoea Alveolaris. Ost. Ung. Vjschr. Zhk., 17 : 279-283, 1901.

2) Stillman, P.R. : The Management of Pyorrhea. Dent. Cosmos, 59 : 405-414, 1917.

3) Glickman, I. \& Leon, A.W. : Role of Trauma from Occlusion in Initiation of Periodontal Pocket Formation in Experimental Animals. J. Periodont., 26 : 14-20, 1955.

4) Polson, A.M. : Trauma and Progression of Marginal Periodontitis in Squirrel Monkeys. J. Periodont. Res., 9 : 108-113, 1973.

5) Polson, A.M. : Trauma and Progression of
Marginal Periodontitis in Squirrel Monkeys. J. Periodont. Res., 11 : 279-289, 1976.

6) Waerhaug, J. : Pathogenesis of Pocket Formation in Traumatic Occlusion. J. Periodont., 26 : 107-118, 1955.

7) Bhaskar, S.N. \& Orban, B. : Experimental Occlusal Trauma. J. Periodont., $26: 270-284$, 1955.

8) Coolidge, E.D. : Traumatic and Functional Injuries occuring in the Supporting Tissues of Human Teeth. J. Amer. Dent. Ass., 25 : 343357, 1938.

9) Lindhe, J. \& Svanberg, G. : Influence of Trauma from Occlusion on Progression of Experimental Periodontitis in the Beagle Dog. J. Clin. Periodont., $1: 3-14,1974$.

10) Linde, J. \& Ericsson, I. : The Effect of Elimination of Jiggling Forces on Periodontally Exposed Teeth in the Dog. J. Periodont., 53 : 562-567, 1982.

11) Polson, A.M., Meitner, S.W., \& Zander, H.A. : Trauma and Progression of Marginal Periodontitis in Squirrel Monkeys. J. Periodont. Res., $11: 290-298,1976$.

12) Kantor, M., Polson, A.M. \& Zander, H.A. : Alveolar bone Regeneration after removal of Inflammatory and Traumatic Forces. J. Periodont., 47 : 687-695, 1976.

13) Löe, H. : The Gingival Index, the Plaque Index and the Retention Index System. J. Periodont., $38: 610-616,1967$.

14) Löe, H. \& Silness, J. : Periodontal Disease in Pregnancy. I. Prevalence and Severuty. Acta odont. Scand., $21: 533-554,1963$.

15) Green, J.C. \& Vermillion, J.R. : The Oral Hygine Index. A Method for classifying Oral Hygine Ststus. J. Amer. Dent. Ass., $61: 172-$ 179, 1960.

16）林 和夫, 護邦忠弘, 三瀬博司, 橋本光示, 藤本 完次，民上良徳，上田雅俊，今井久夫，山岡 昭: 歯周疾患における病態の推移とポケット浸出液量 との関連性について. 日歯周誌, $19: 231-238$, 1977.

17) Brill, N. : Gingival Condition related to Flow 
to Tissue Fluid into Gingival pockets. Acta odont. Scand., $18: 421-446,1960$.

18）渡辺 久, 石川 烈：歯肉溝浸出液の測定法とそ の意義について. 歯科ジャーナル, $17: 225-233$, 1983.

19) Irwin, J.P., Victor, E.B. \& Alan, B.S. : A Technique for Standardized Serial Dental Radiographs. J. Periodont., 42 : 297-299, 1971.

20）川崎 仁：口内法による個体 $\mathrm{X}$ 線規格撮影とその 歯周疾患への応用. 口病誌, $34: 164-180,1967$.

21）民上良徳 : Infrabony pocket への Plaster implant 応用に関する実験的研究. 日歯周誌, 25 : 9-43, 1982.

22）杉村忠敬 : 咬合力に対する歯および下顎骨の力学 的反応機構に関する実験的研究. 日 本補 綴 誌, $23: 512-536,1979$.

23）谷口 勉 : 補緅学上からみた外傷性咬合の実験的 研究. 歯科医学, $28: 330-367,1965$.

24) Waerhaug, J. \& Hansen, E.R. : Periodontal Changes Incident to Prolonged Occlusal Overload in Monkeys. Acta odont. Scand., 24 : 91105, 1966.

25）本間 博, 池田直人, 石川 純 : 実験的咬合性外 傷と歯周炎のサル歯周組織破壊に及ぼす影響につ いて. 日歯周誌, $19: 220-230,1977$.

26）本間 博 : 実験的咬合性外傷のサル歯周組織に及 ぼす影響に関する研究. 日歯周誌, $19: 289-302$, 1977.

27) Wentz, F.M., Jarabak, J. \& Orban, B. : Experimental Occlusal Trauma Imitating cuspal Interference. J. Periodont., 29 : 117-127, 1958.

28) Glickman, I. \& Smulow, J.B. : Adaptive Alterlations in the Periodontium of the Phesus Monkey in Chronic Trauma from Occlusion. J. Periodont., 39 : 101-105, 1968.

29) Macapanpan, L.C. \& Weinmann, J.P. : The Influence of Injury to the Periodontal Membrane on the Spread of Gingival Inflamation. J. Dent. Res., 33 : 263-272, 1954.
30）加藤 㵙 : 咬合性外傷の治療. 歯科ジャーナル, $7: 321-331,1978$.

31）加藤 㜯：咬合状態の診査. 歯科ジャーナル, 5 : 295-307, 1977.

32）加藤 㜯：咬合性外傷とその処置一咬合調整. 歯 界展望ペリオドンティックスの臨床，201-224， 1977.

33）国島康夫, 黒田昌彦, 小坂橋誠, 谷口威夫 : 咬合 調整量をめぐって，歯界展望, $60 ： 237-256,1983$.

34) Safavi, H., Ruben, M.P., Mafla, E.R. \& Bloom, A.A. : Periodontal Traumatism Produced by Sustained Increase in Occlusal Vertical Dimension. A Histopathological Study. J. Periodont., 45 : 207-216, 1974.

35）天野仁一朗：咬合・咀嚼運動および燕下運動時の 顎骨のひずみについて． 歯科基礎誌，12:52-87, 1970.

36）宮地建夫：咬合圧によって生ずる歪分布からみた 動物顔面頭蓋の構造力学的研究. 歯科学報, 71 : 44-91, 1971.

37）芳本 忍：咬合力に対する下䫟骨の力学的反応に ついて. 歯科基礎誌, $18: 286-310,1976$.

38) Glickman, I. \& Smulow, J.B. : Alteration in the Pathway of Gingival Inflammation into the Underlying Tissues Induced by Excessive Occlusal Forces. J. Periodont., 33 : 7-13, 1962.

39) Glickman, I. \& Smulow, J.B. : Effect of Excessive Occlusal Force Upon the Pathway of Gingival Inflammation in Humans. J. Periodont., 36 : 141-147, 1965.

40) Glickman, I. \& Smulow, J.B. : Further Observation on the Effect of Trauma from Occlusion in Humans. J. Periodont., 38 : 280-293, 1967.

41）浦井照彦：実験的外傷性咬合による歯周組織の変 化に関するX線学的研 究. 日歯周誌, $15: 173$ 1973.

42）林田定昭，中村正利：イエテボリ大学歯周病科に おける Post-Graduate Course. 歯科ジャーナル, 15 : 615-624, 1982. 


\section{図説明}

Control sites

Fig. 9 Roentgenogram of 0 week after high crown setting

Fig. 10 Roentgenogram of 58 weeks after high crown setting

Experimental sites

Fig. 11 Roentgenogram of 0 week after high crown setting

Fig. 12 Roentgenogram of 2 weeks after high crown setting

Fig. 13 Roentgenogram of 6 weeks after high crown setting

Fig. 14 Roentgenogram of 8 weeks after high crown setting

Fig. 15 Roentgenogram of 11 weeks after high crown setting

Fig. 16 Roentgenogram of 4 weeks after occlusal adjustment

Fig. 17 Roentgenogram of 7 weeks after occlusal adjustment

Fig. 18 Roentgenogram of 12 weeks after occlusal adjustment

Fig. 19 Roentgenogram of 25 weeks after occlusal adjustment

Fig. 20 Roentgenogram of 42 weeks after occlusal adjustment

Fig. 21 Roentgenogram of 58 weeks after occlusal adjustment

Control sites

Fig. 22 Photo-pattern (A) of 0 week after high crown setting

Fig. 23 Photo-pattern (A) of 58 weeks after high crown setting

Experimental sites

Fig. 24 Photo-pattern (A) of 0 week after high crown setting

Fig. 25 photo-pattern (A) of 2 weeks after high crown sstting

Fig. 26 Photo-pattern (A) of 6 weeks after high crown setting

Fig. 27 Phoło-pattern (A) of 8 weeks after high crown setting

Fig. 28 Photo-pattern (A) of 11 weeks after high crown setting

Fig. 29 Photo-pattern (A) of 4 weeks after occlusal adjustment

Fig. 30 Photo-pattern (A) of 7 weeks after occlusal adjustment

Fig. 31 Photo-pattern (A) of 12 weeks after occlusal adjustment

Fig. 32 Photo-pattern (A) of 25 weeks after occlusal adjustment

Fig. 33 Photo-pattern (A) of 42 weeks after occlusal adjustment

Fig. 34 Photo-pattern (A) of 58 weeks after occlusal adjustment

Control sites

Fig. 35 Photo-pattern (B) of 0 week after high crown setting

Fig. 36 Photo-pattern (B) of 58 weeks after high crown setting

Experimental sites

Fig. 37 Photo-pattern (B) of 0 week after high crown setting

Fig. 38 Photo-pattern (B) of 2 weeks after high crown setting

Fig. 39 Photo-pattern (B) of 6 weeks after high crown setting

Fig. 40 Photo-pattern (B) of 8 weeks after high crown setting

Fig. 41 Photo-pattern (B) of 11 weeks after high crown setting

Fig. 42 Photo-pattern (B) of 4 weeks after occlusal adjustment

Fig. 43 Photo-pattern (B) of 7 weeks after occlusal adjustment

Fig. 44 Photo-pattern (B) of 12 weeks after occlusal adjustment

Fig. 45 Photo-pattern (B) of 25 weeks after occlusal adjustment

Fig. 46 Photo-pattern (B) of 42 weeks after occlusal adjustment

Fig. 47 Photo-pattern (B) of 58 weeks after occlusal adjustment 
CONTROL 0w

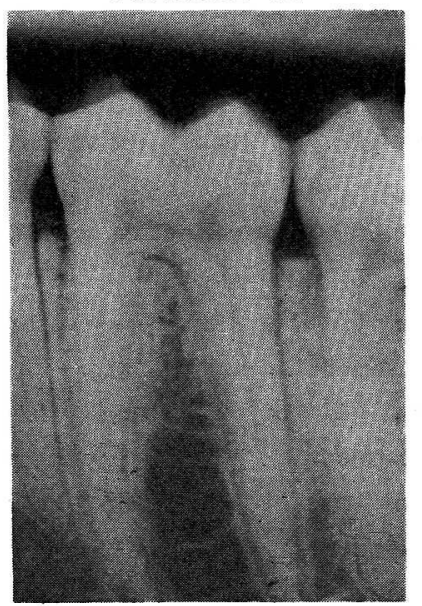

Fig. 9

CONTROL $59 \mathrm{w}$

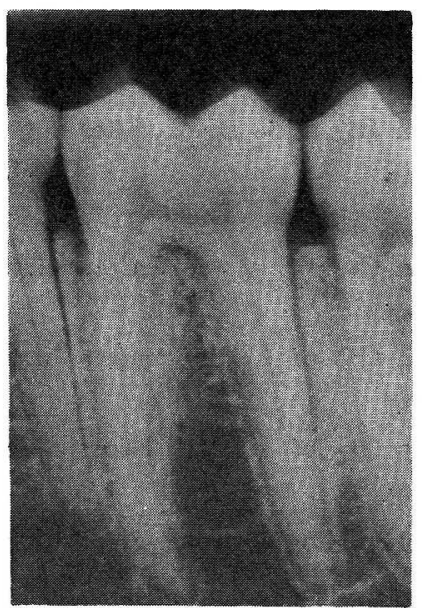

Fig. 10

$0 \mathrm{w}$

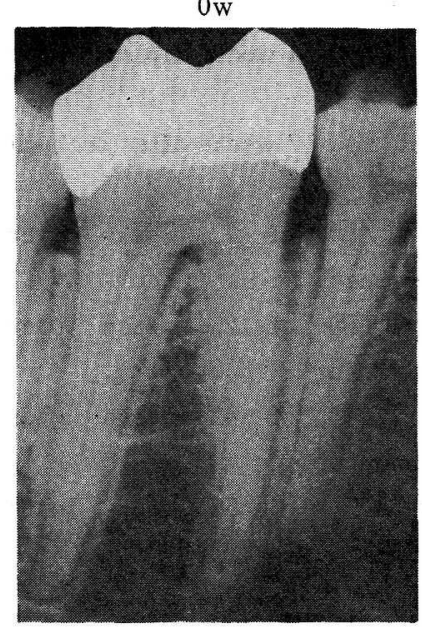

Fig. 11

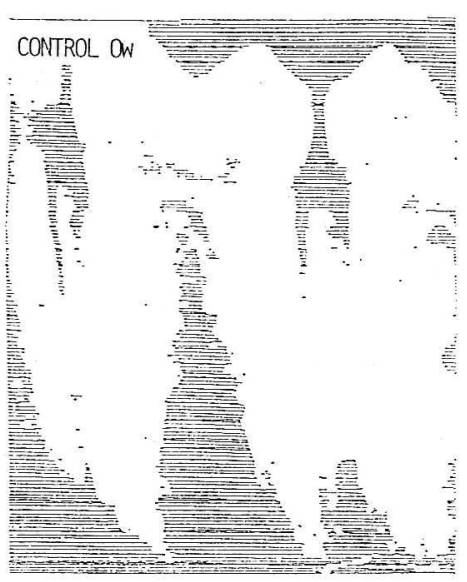

Fig. 22

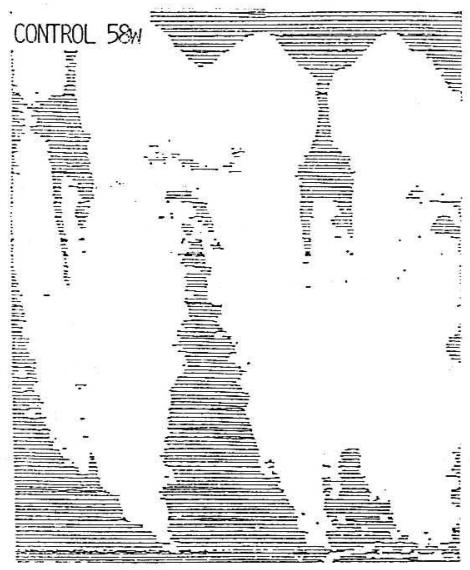

Fig. 23

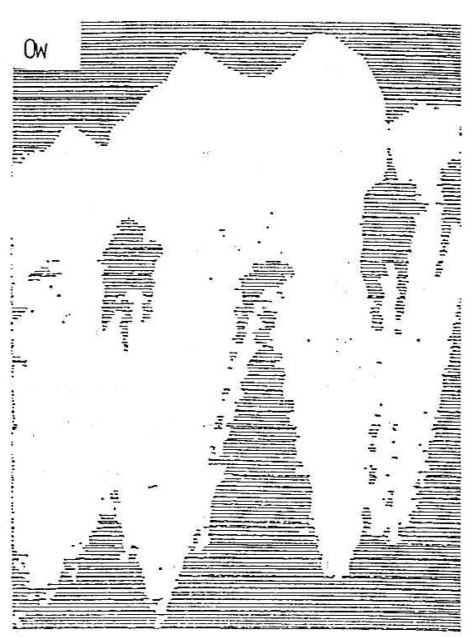

Fig. 24

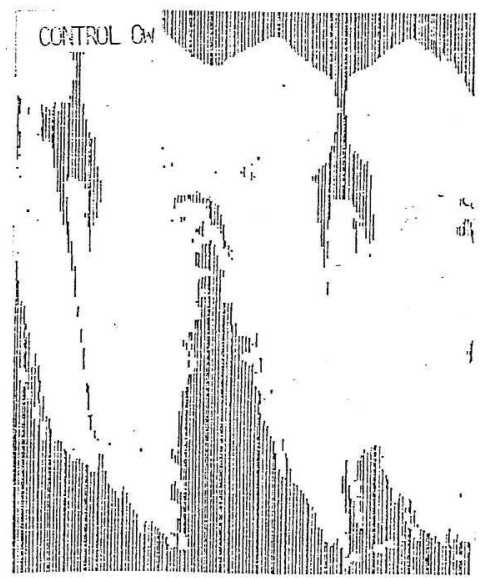

Fig. 35

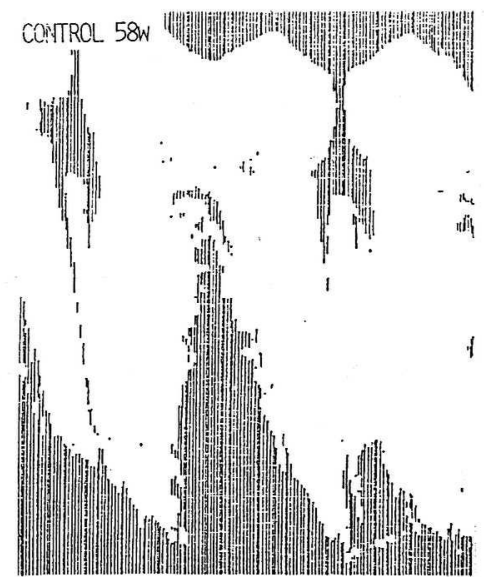

Fig. 36

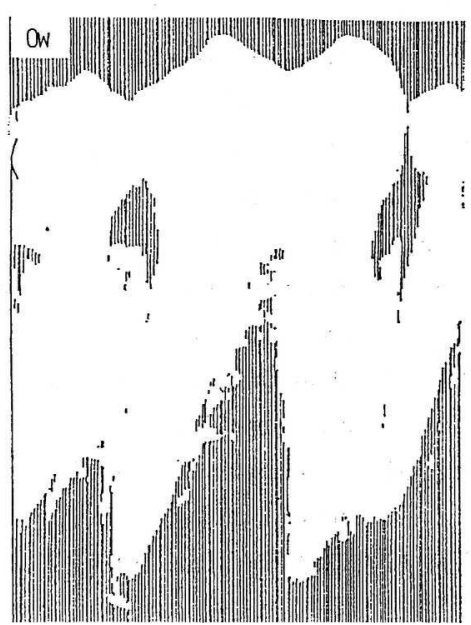

Fig. 37 


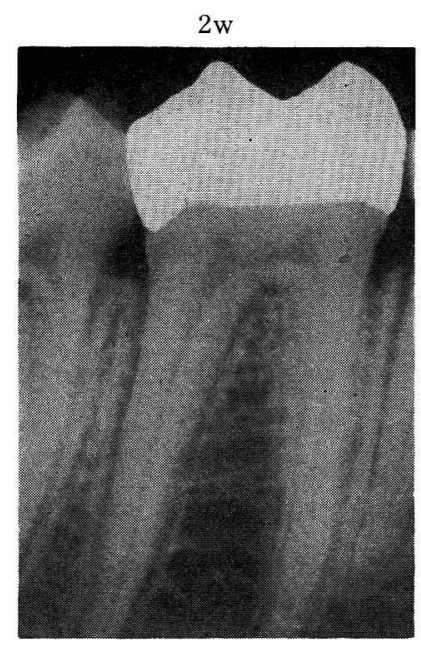

Fig. 12

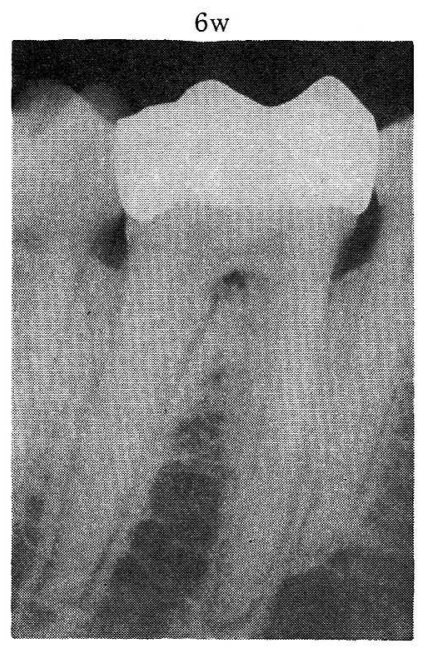

Fig. 13

$8 \mathrm{w}$

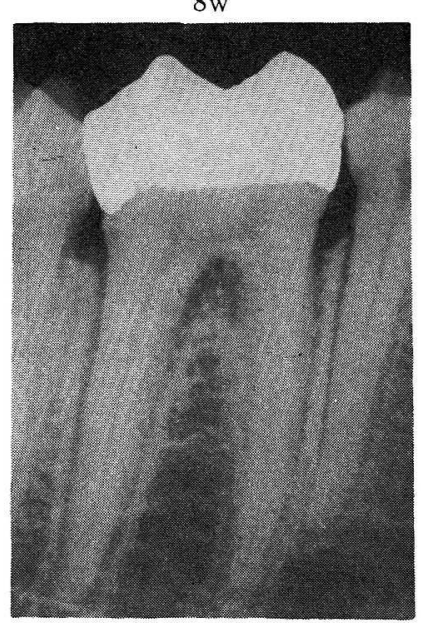

Fig. 14

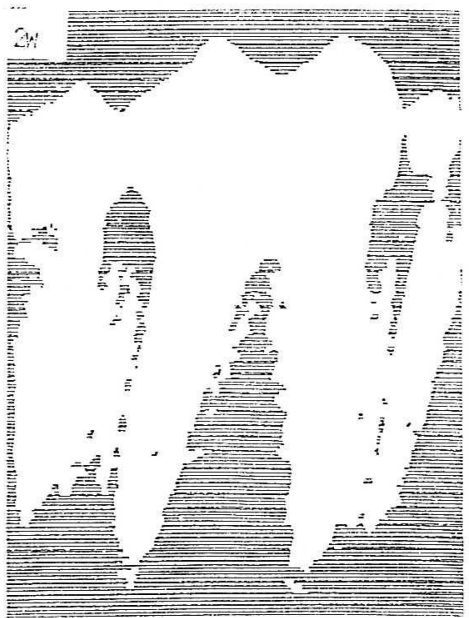

Fig. 25

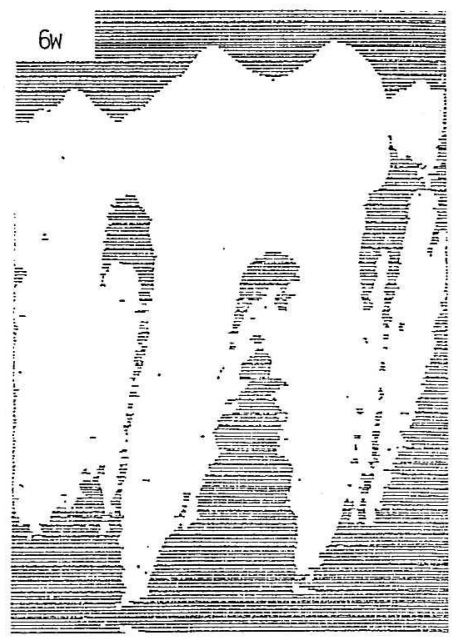

Fig. 26

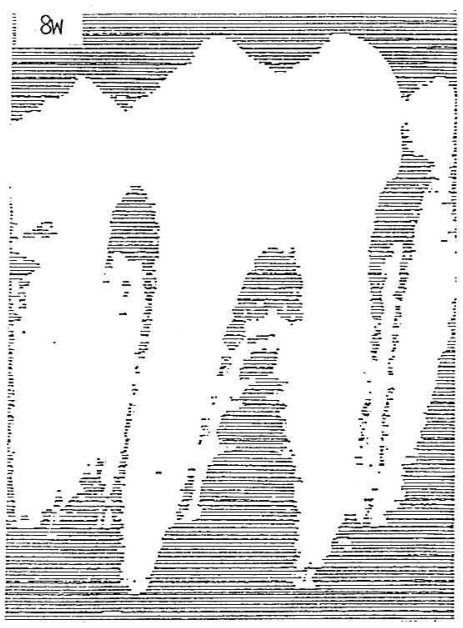

Fig. 27

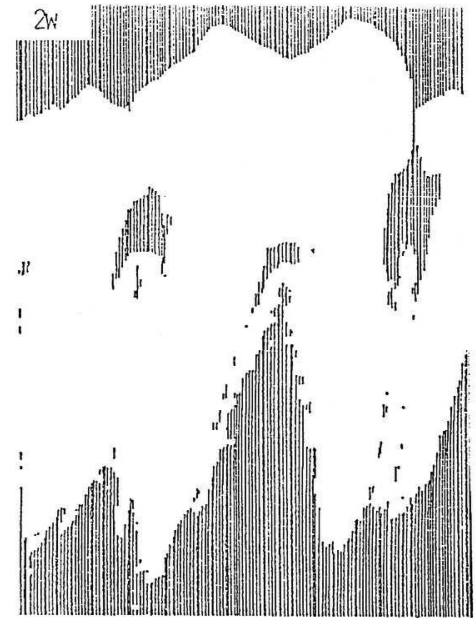

Fig. 38
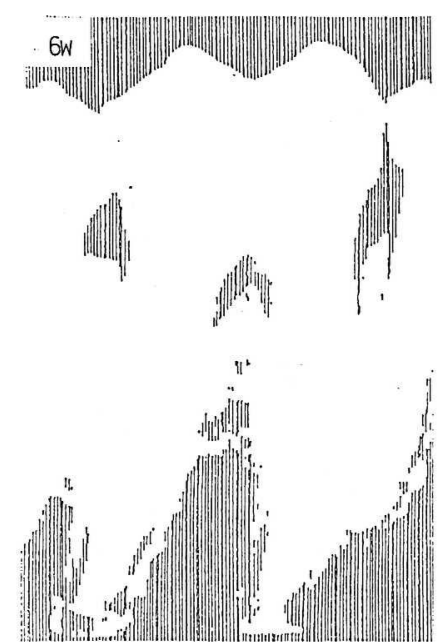

Fig. 39
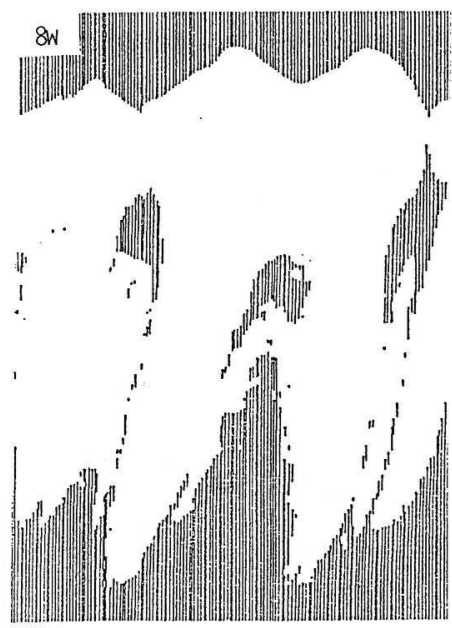

Fig. 40 


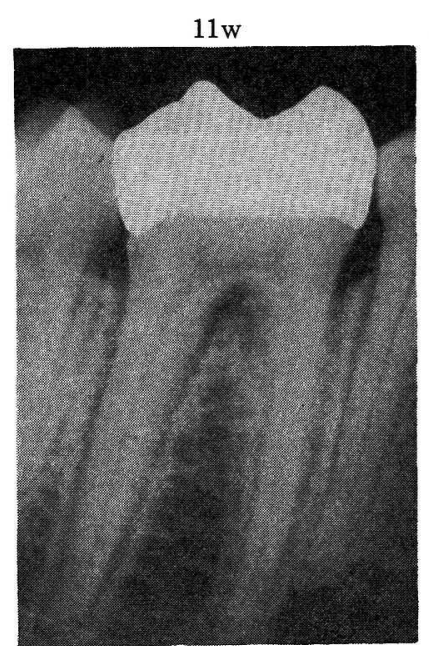

Fig. 15

4w

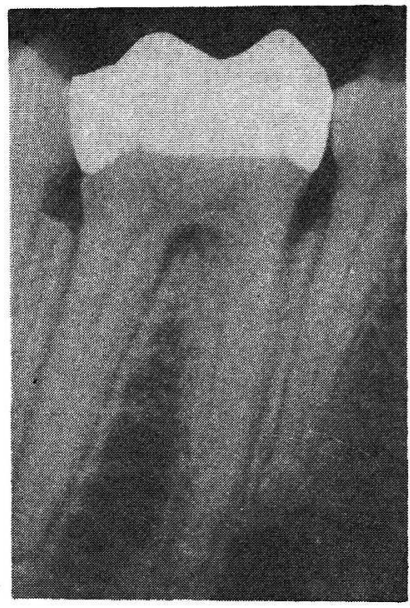

Fig. 16

$7 \mathrm{w}$

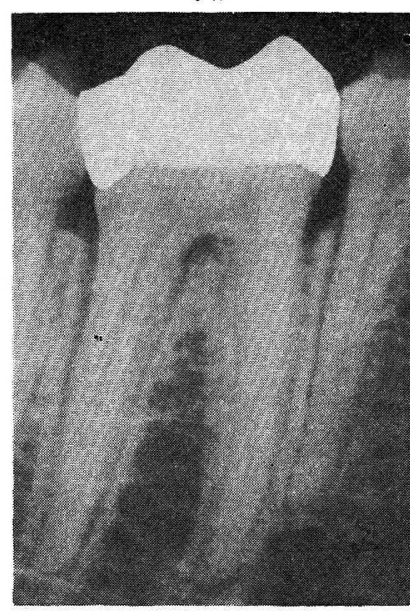

Fig. 17

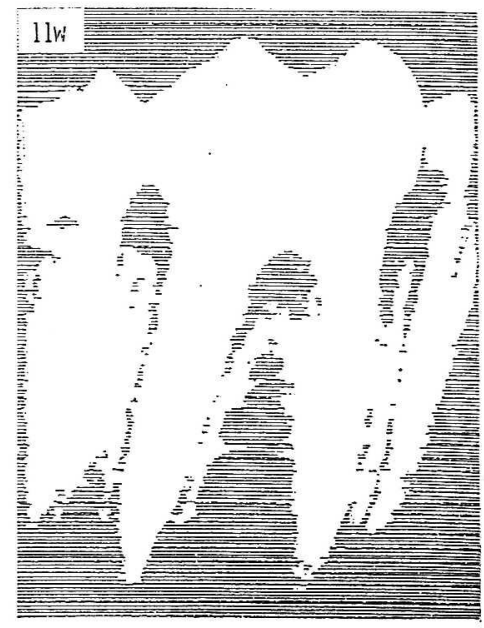

Fig. 28

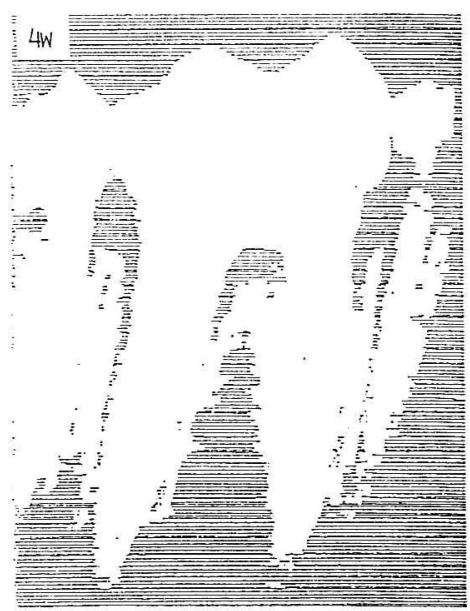

Fig. 29

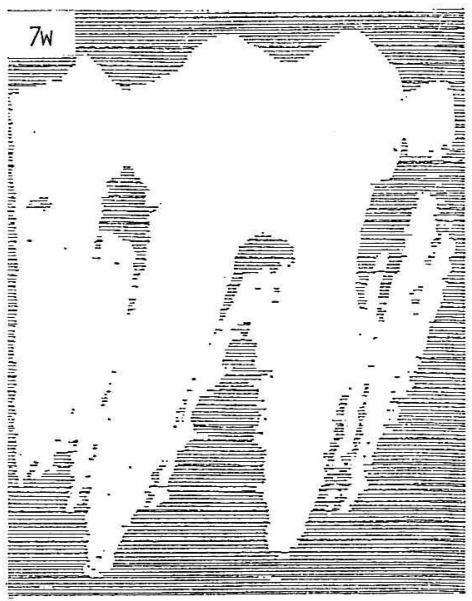

Fig. 30

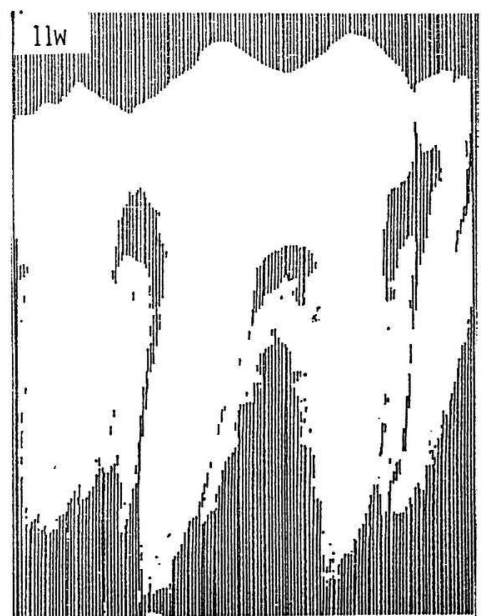

Fig. 41
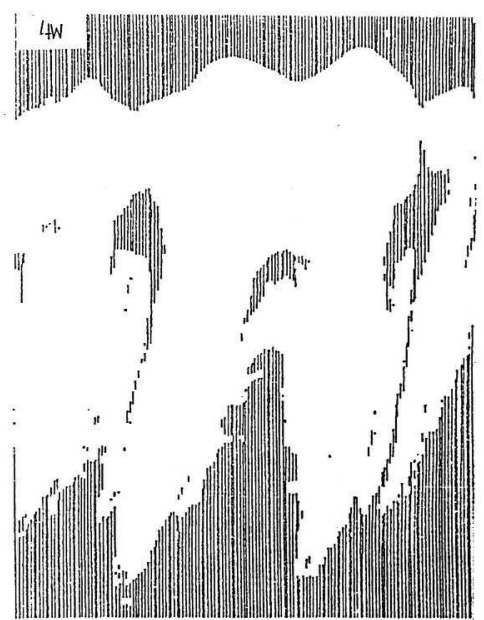

Fig. 42

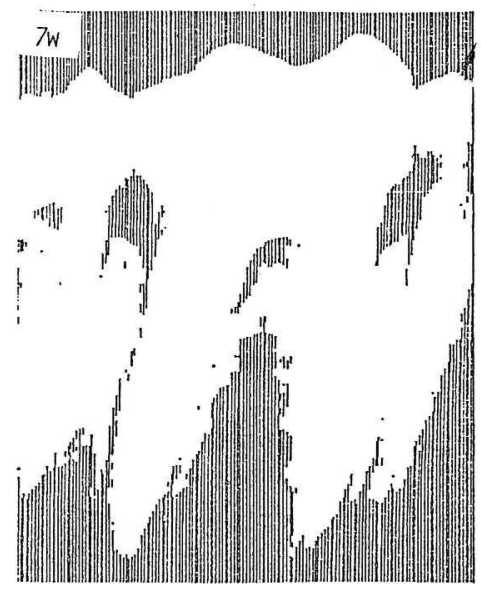

Fig. 43 
$12 \mathrm{w}$

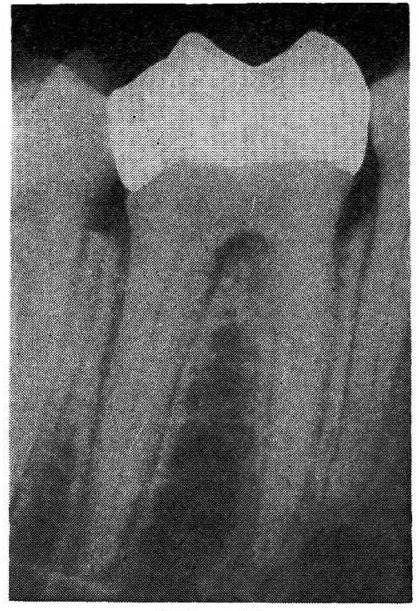

Fig. 18

$25 \mathrm{w}$

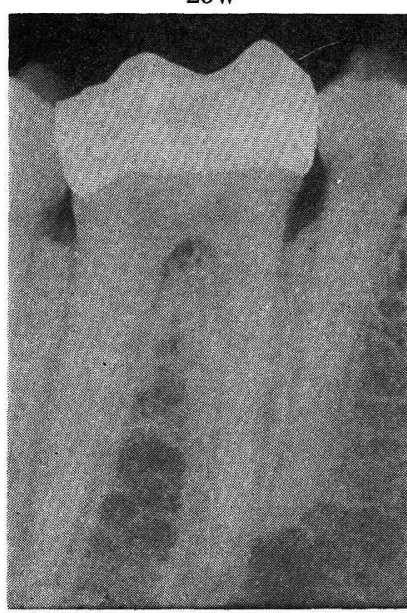

Fig. 19

$42 \mathrm{w}$

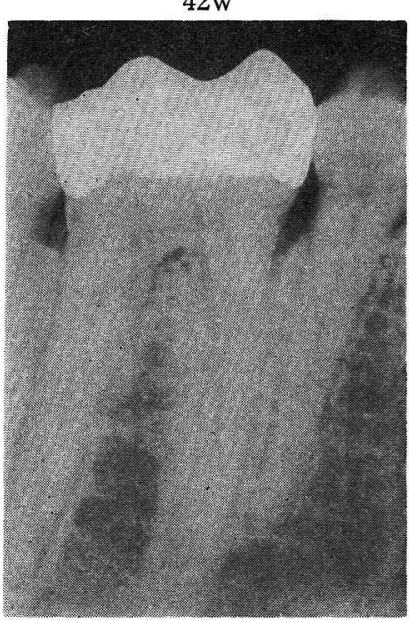

Fig. 20

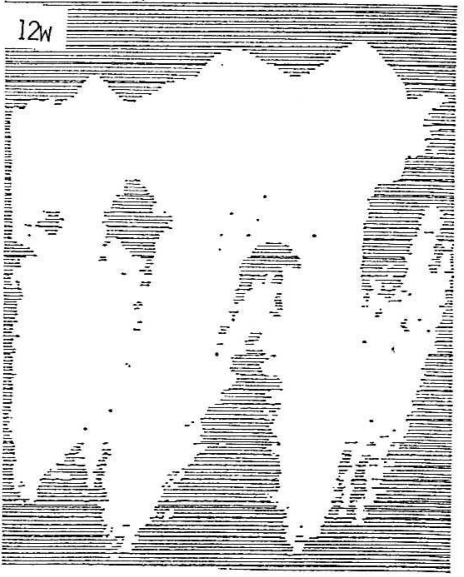

Fig. 31
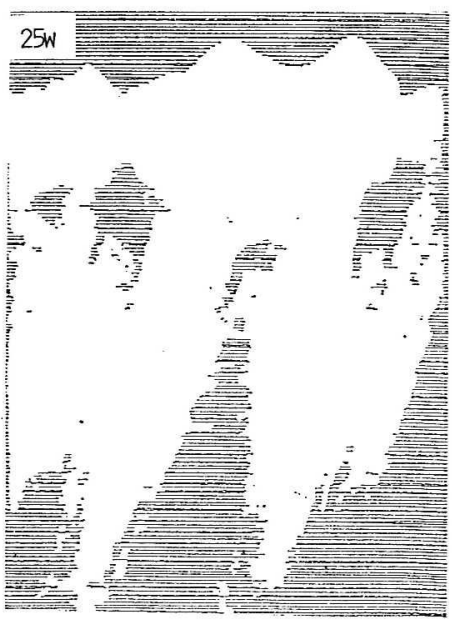

Fig. 32

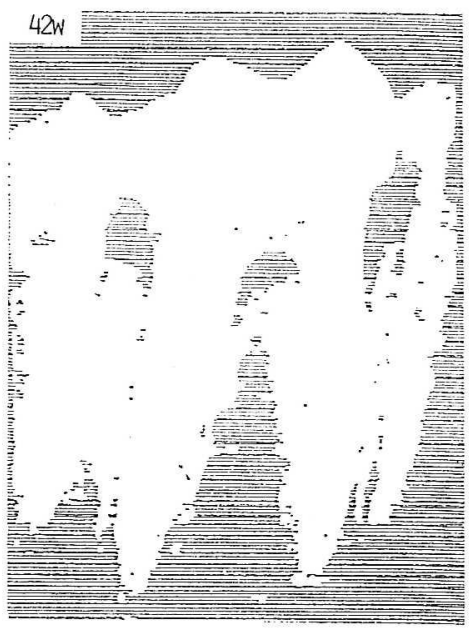

Fig. 33

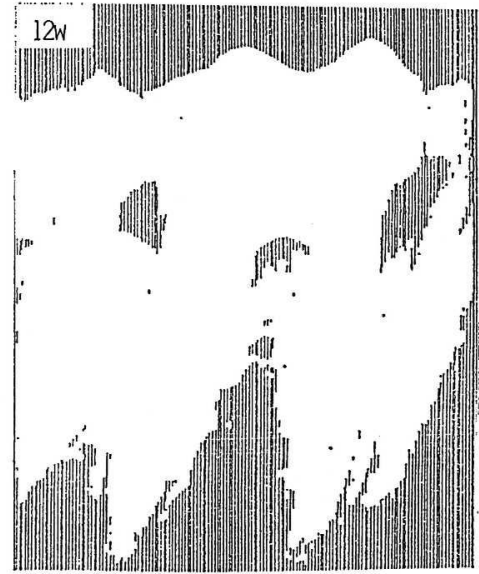

Fig. 44
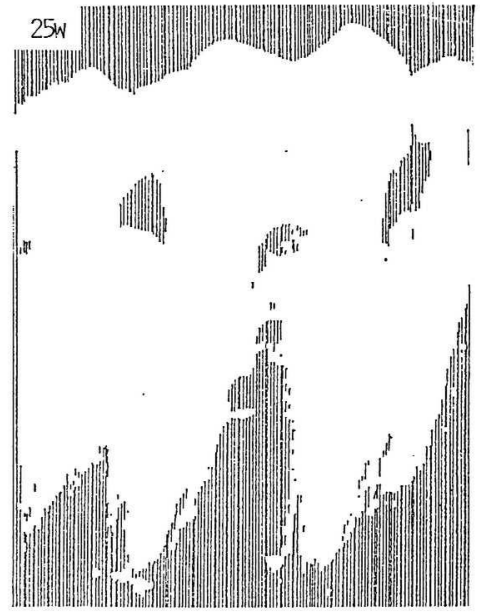

Fig. 45
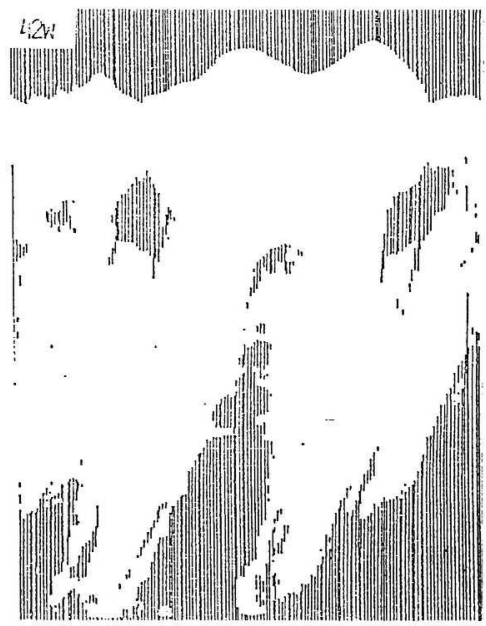

Fig. 46 
58w

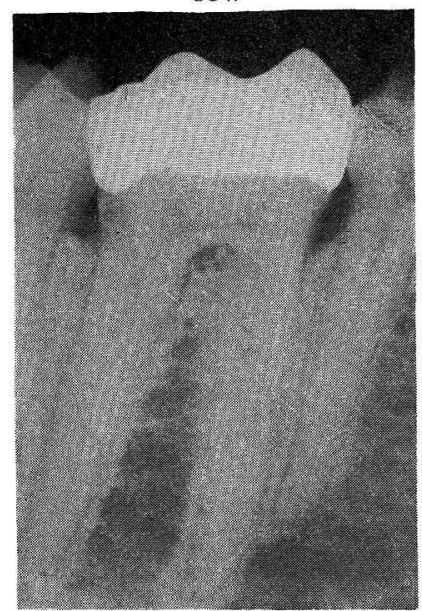

Fig. 21

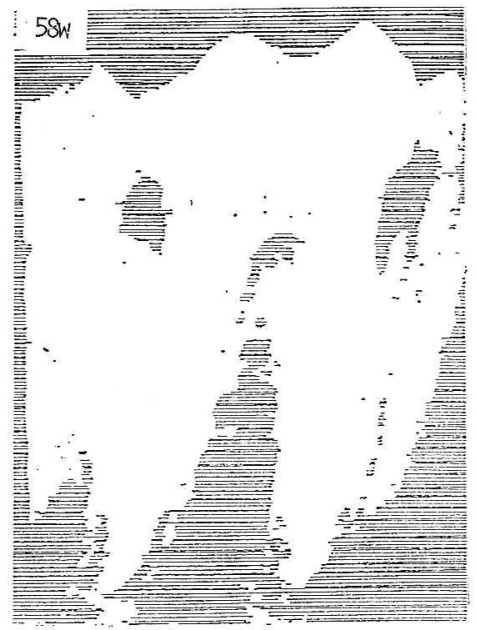

Fig. 34

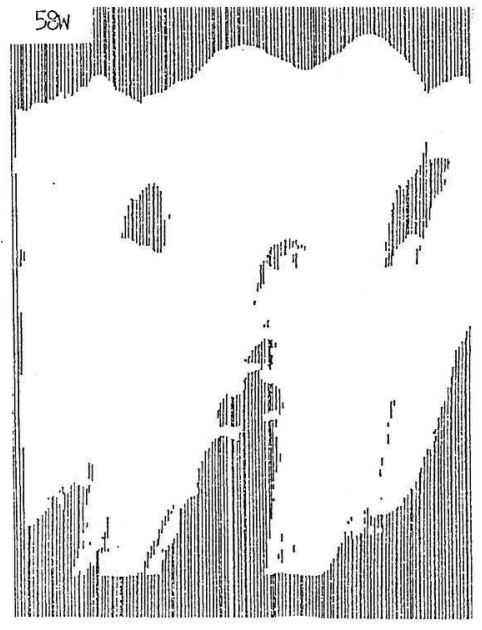

Fig. 47 